\title{
AN ASSESSMENT OF THE RADIOCARBON DATING OF THE DEAD SEA SCROLLS
}

\section{G. A. RODLEY}

Pharmacy Department, University of Sydney, Sydney NSW 2006 Australia

ABSTRACT. I suggest, on the basis of a statistical analysis, that recently determined "conventional radiocarbon ages" of Dead Sea Scroll documents are offset systematically by about $+40 \mathrm{yr}$, leading to a similar overestimate of the ages of these documents. Much closer agreement with paleographic and specific dates is obtained when a correction of this magnitude is made to the "conventional ${ }^{14} \mathrm{C}$ " values. This indicates that ${ }^{14} \mathrm{C}$ dates may convey more precise information about the ages of these documents than initially recognized.

\section{INTRODUCTION}

Bonani et al. $(1991,1992)$ recently published details of a ${ }^{14} \mathrm{C}$ dating study of Dead Sea Scroll documents. This was based on the quasi-simultaneous determination of ${ }^{14} \mathrm{C} /{ }^{12} \mathrm{C}$ and ${ }^{13} \mathrm{C} /{ }^{12} \mathrm{C}$ ratios relative to standard NBS (PDB) values (Stuiver \& Pearson 1986). The authors made corrections for natural fractionation (Stuiver \& Polach 1977) and presented the results as conventional ${ }^{14} \mathrm{C}$ ages. Each value corresponded to the weighted mean date of several independent measurements of differently prepared samples of each document. Error ranges were quoted as either the statistical error (one standard deviation $(1 \sigma)$ ) or the variance, whichever was the higher.

Conventional ${ }^{14} \mathrm{C}$ ages were converted to "calibrated $1 \sigma{ }^{14} \mathrm{C}$ age ranges" using the high-precision calibration curve of Stuiver and Pearson (1986) and Wölfli (1987). These values were compared with specific dates and paleographically determined age ranges (Bonani et al. 1991).

In their initial paper, Bonani et al. $(1991: 29,31)$ stated that: 1) agreement with the four "datebearing" scrolls indicates "no methodical offset, either in the radiocarbon method or in the calibration curve ..."; and 2) "our research put to test both the radiocarbon method and paleography: seemingly, both disciplines have fared well." However, in a subsequent paper, Bonani et al. (1992: 847) commented that “ . . . a slight systematic shift between the calibrated radiocarbon ages and the estimates of the paleographers might be inferred from the data. The calibrated radiocarbon ages are, on average, 35 years older. The statistical significance of this offset remains to be proven." This offset may be appreciated by reference to the plot of the data in Bonani et al. (1991: Fig. 2), which shows that most of the ${ }^{14} \mathrm{C}$ estimates are older than paleographic dates.

\section{ANALYSIS}

To evaluate possible systematic displacement of the ${ }^{14} \mathrm{C}$ results, I performed a statistical analysis of these data (excluding Sample 2, which involves a major discrepancy of unknown origin (Bonani et al. 1991)). First, I determined sets of specific age values from Table 1:

1. I obtained specific calibrated ${ }^{14} \mathrm{C}$ ages (Table 1) from the set of specific ${ }^{14} \mathrm{C}$ conventional age values given in Bonani et al. (1991, Table 1), derived using Table 3 of Stuiver and Pearson (1986). In the case of Sample 1, I used the higher of the two possible ${ }^{14} \mathrm{C}$ values and the younger value for Sample 5.

2. I obtained a set of paleographic/specified dates by taking the midpoints of the ranges given in the last column of Table 1 (Bonani et al. 1991), together with specified dates for documents $1,12,13$ and 14. I list these values in Table 1 under the heading "Paleographic or specified (P/S) age". 
Linear least-squares regression analysis of the two sets of values yielded the resulting ${ }^{14} \mathrm{C}$ age $=$ $41.6+0.992(\mathrm{P} / \mathrm{S})$, at a $\mathrm{R}^{2}(\mathrm{adj})$ value of $97.9 \%$. A T-test and a Wilcoxon-test of $\left({ }^{14} \mathrm{C}-\mathrm{P} / \mathrm{S}\right)$ values gave similar "offset" values of 41.8 and $44.5 \mathrm{yr}$ (with $\mathrm{P}$ values of 0.001 and 0.006 ). These tests indicate strongly a systematic difference of $c a .40 \mathrm{yr}$ between the ${ }^{14} \mathrm{C}$ measurements and paleographic estimates. Using the first two estimates, I chose to decrease the conventional ${ }^{14} \mathrm{C}$ ages reported in Table 1 of Bonani et al. (1991) by $42 \mathrm{yr}$. A new set of "adjusted ${ }^{14} \mathrm{C}$ ages" was then determined using Table 3 of Stuiver and Pearson (1986). An exception was Sample 14, where the value was determined from the higher-precision calibration curve (Stuiver \& Becker 1986) by assuming that the experimental value actually corresponded to the dip in the curve at about $\mathrm{AD} 730$, rather than the alternative $\mathrm{AD} 770$ region. The adjusted value of $1289-42=1247 \mathrm{BP}$ would have to be increased only by a few years to intercept the $\mathrm{AD} 730$ region; this is reasonable in terms of the estimated error in the experimental value. Table 1 gives the new set of calibrated ages, under "Adjusted ${ }^{14} \mathrm{C}$ age". While specific age values, rather than age ranges, were used for the statistical analysis, an adjusted set of age ranges may be determined from the ${ }^{14} \mathrm{C}$ ages (yr BP) of Bonani et al. (1991) by subtracting the $42 \mathrm{yr}$ from each entry and using the error values listed.

\section{Discussion}

The statistical analysis, coupled with the offset of specific calibrated ${ }^{14} \mathrm{C}$ ages from the paleographic or specified ages strongly suggest a systematic displacement of the ${ }^{14} \mathrm{C}$ values. It is possible that the discrepancy arises from varying ages of the materials on which the documents were written. However, it is unlikely that the materials would be consistently older (by ca. $40 \mathrm{yr}$ ) than the times of writing.

What is more likely is that, with the particular procedures involved in obtaining "conventional" ${ }^{14} \mathrm{C}$ values (Stuiver \& Polach 1977), a systematic offset of $c a .40$ yr. resulted. Bonani et al. (1991) followed the recommended procedure of reporting conventional ${ }^{14} \mathrm{C}$ ages without adjustment (Stuiver \& Polach 1977), and correctly noted the general agreement of the derived calibrated age ranges with the paleographic/specified ages. It is possible that the offset could be due to either 1) small errors in age, arising in the use of the equations of Stuiver and Polach (1977), when the isotope ratio ${ }^{13} \mathrm{C} /{ }^{12} \mathrm{C}$ is not adequately determined (although an instrumental error in this determination would result in scatter of the points) or 2) a small calculation error in the isotope correction.

If it is accepted that an offset exists, the reported ${ }^{14} \mathrm{C}$ ages may be decreased by a fixed amount; I chose $42 \mathrm{yr}$ based on the statistical analysis. The new set of adjusted ${ }^{14} \mathrm{C}$ ages (Table 1) shows good overall agreement with the paleographic and specified ages (especially for Samples 1, 12, 13 and 14 that have specified dates). This indicates that the ${ }^{14} \mathrm{C}$ dating study may be more significant than initially indicated (Bonani et al. 1991). I suggest that the paleographic estimate for Sample 8 , which shows a marked discrepancy with the corresponding "adjusted" ${ }^{14} \mathrm{C}$ value, may require revision, if the possibility that the document studied is a later copy of an earlier original can be eliminated. The result for Sample 11 may be a good indication of the age of a document for which the paleographic estimate covers a relatively wide age range. The residual difference of $44 \mathrm{yr}$ for Sample 7 also may be significant.

Samples 12 and 13 provide evidence for the merit of the analysis presented here. The values reported by Bonani et al. (1991) of 1917 BP (Sample 12) and 1892 BP (Sample 13) fall in a shallow region of the calibration curve that shows a significant difference of $20 \mathrm{yr}$ in the corres- 
TABLE 1. Specific Age Values for Scroll Documents

\begin{tabular}{|c|c|c|c|c|}
\hline Scroll no. & Description & $\mathrm{Cal}{ }^{14} \mathrm{C}$ age ${ }^{*}$ & $\mathrm{P} / \mathrm{S}$ age** & Adjusted ${ }^{14} \mathrm{C}$ age ${ }^{*}$ \\
\hline 1 & Daliyeh & $390(39) \mathrm{BC}$ & $351 \mathrm{BC}(\mathrm{S})$ & $373(22) \mathrm{BC}$ \\
\hline 2 & Testament of Qahat & \multicolumn{3}{|c|}{ (not included in analysis - refer to text) } \\
\hline 3 & Pentateuchal paraphrase & $186(75) \mathrm{BC}$ & $111 \mathrm{BC}$ & $115(4) \mathrm{BC}$ \\
\hline 4 & Book of Isaiah & $176(65) \mathrm{BC}$ & $111 \mathrm{BC}$ & $109(-2) \mathrm{BC}$ \\
\hline 5 & Testament of Levi & $173(73) \mathrm{BC}$ & $100 \mathrm{BC}$ & $107(7) \mathrm{BC}$ \\
\hline 6 & Book of Samuel & $114(28) \mathrm{BC}$ & $86 \mathrm{BC}$ & $80(-6) \mathrm{BC}$ \\
\hline 7 & Masada - Joshua & 109(94) BC & $15 \mathrm{BC}$ & $59(44) \mathrm{BC}$ \\
\hline 8 & Masada - Sectarian & AD 22(-37) & $15 \mathrm{BC}$ & $\mathrm{AD} 72(-87)$ \\
\hline 9 & Temple Scroll & $43(43) \mathrm{BC}$ & 0 & $\mathrm{AD} 9(-9)$ \\
\hline 10 & Genesis Apocryphon & $24(24) \mathrm{BC}$ & 0 & $\mathrm{AD} 22(-22)$ \\
\hline 11 & Thanksgiving Scroll & $\mathrm{AD} 16(-6)$ & $\mathrm{AD} 10$ & $\mathrm{AD} 68(-58)$ \\
\hline 12 & Wadi Seyal & $\mathrm{AD} 79(51)$ & $\mathrm{AD} 130(\mathrm{~S})$ & $\mathrm{AD} 121(9)$ \\
\hline 13 & Murabba'at & AD $99(35)$ & AD 134(S) & $\mathrm{AD} 135(-1)$ \\
\hline 14 & Kh. Mird & $\mathrm{AD} 685(59)$ & $\mathrm{AD} 744(\mathrm{~S})$ & $\mathrm{AD} 735(9)^{\dagger}$ \\
\hline
\end{tabular}

* Values in brackets are differences with respect to the paleographic or specified ages

**P/S age = paleographic or specified age

${ }^{\dagger}$ Value based on higher conventional ${ }^{14} \mathrm{C}$ age than determined in adjustment procedure (see text)

ponding cal ages (AD 79 and $\mathrm{AD} 99$ ). By contrast, my adjustment of $42 \mathrm{yr}$ brings the new values of 1875 and $1850 \mathrm{BP}$ into a steeper area of the curve. The effect is more apparent with the higherprecision curves and data of Stuiver and Becker (1986) than for the values given in Table 1 (derived from Stuiver and Pearson (1986)). The values obtained are AD 126 and 131, which closely correspond to the specified values of $\mathrm{AD} 130-31$ and $\mathrm{AD} 134$. The conventional ${ }^{14} \mathrm{C}$ ages must be associated with a steep part of the calibration curve for such different values to give similar calibrated ages.

\section{CONCLUSION}

I based this analysis on specific age values and have not taken error margins into account. However, these results indicate the ${ }^{14} \mathrm{C}$ dating of the Dead Sea Scroll documents may be more informative than initially indicated (Bonani et al. 1991). I also suggest that a general accuracy of about $\pm 25 \mathrm{yr}$ has been achieved, making the method especially useful for documents whose ages are otherwise in doubt.

\section{ACKNOWLEDGMENT}

I wish to thank Dr. Igor Gonda for helpful comments. 


\section{REFERENCES}

Bonani, G., Broshi, M., Carmi, I., Ivy, S., Strugnell, J. and Woelfli, W. 1991 Radiocarbon dating of the Dead Sea Scrolls. 'Atiqot 20: 27-32.

Bonani, G., Ivy, S., Wölfli, W., Broshi, M., Carmi, I. and Strugnell, J. 1992 Radiocarbon dating of fourteen Dead Sea Scrolls In Long, A. and Kra, R. S., eds., Proceedings of the 14 th International ${ }^{14} \mathrm{C}$ Conference. Radiocarbon 34(3): 843-849.

Stuiver, M. and Becker, B. 1986 High-precision decadal calibration of the radiocarbon time scale, $\mathrm{AD} 1950$ 2500 BC. In Stuiver, M. and Kra, R. S., eds., Proceedings of the 12 th International ${ }^{14} \mathrm{C}$ Conference. Radiocarbon 28(2B): 863-910.
Stuiver, M. and Pearson, G. W. 1986 High-precision calibration of the radiocarbon time scale, AD 1950 500 BC. In Stuiver, M. and Kra, R. S., eds., Proceedings of the 12th International ${ }^{14} \mathrm{C}$ Conference. Radiocarbon 28(2B): 805-838.

Stuiver, M. and Polach, H. A. 1977 Discussion: Reporting of ${ }^{14} \mathrm{C}$ data. Radiocarbon 19(3): 355-363.

Wölfli, W. 1987 Advances in accelerator mass spectrometry. In Gove, H. E., Litherland, A. E. and Elmore, D., eds., Proceedings of the 4th International Symposium on Accelerator Mass Spectrometry, Nuclear Instruments and Methods in Physics Research B29: 1-13. 